\title{
Meningkatkan Jiwa Kewirausahaan Petani Gunung Leuser Kabupaten Langkat
}

\author{
M. Umar Maya Putra ${ }^{1)} \mid$ Syafrida Damanik ${ }^{2)}$ \\ ${ }^{1,2)}$ Universitas Al Azhar \\ umaryazli2017@gmail.com | ridamanik19@gmail.com
}

\begin{abstract}
Abstrak: Pengabdian Kemitraan Masyarakat ini merupakan konsep aplikasi kuliah kewirausahaan dalam Program Studi Manajemen kewirausahaan di Fakultas Ekonomi Universitas Al Azhar berdasarkan Program Pemberdayaan Masyarakat, diharapkan para petani mengetahui pentingnya kewirausahaan dalam meningkatkan bisnis dan dilanjutkan . Metode yang akan digunakan adalah metode pembelajaran eksperimental dan konsep studi kepustakaan tentang kewirausahaan. Penyampaian berupa ceramah, diskusi kelompok sehingga orang dapat berpartisipasi aktif dalam kegiatan ini. Dalam pelatihan disajikan materi: Konsep berwirausaha. Setelah kegiatan dilakukan, ditemukan bahwa peserta cukup responsif dan antusias dalam mengikuti materi pelatihan, sebagaimana dibuktikan oleh banyaknya pertanyaan yang diajukan oleh para peserta dan ada rencana bisnis yang dibuat untuk membuatnya setelah mendapatkan pelatihan melalui di Universitas Al Azhar.
\end{abstract}

Kata Kunci: kewirausahaan, pengembangan, gunung, leuser

\section{Pendahuluan}

Dalam proses pengajuan Kemitraan konservasi berdasarkan dengan Perditjen no 6 tahun 2018 tentang Petunjuk Teknis Kemitraan Konservasi harus ada kelompok/ unit baik yang dibentuk dari desa ataupun kelompok masyarakat tani yang berkomitmen untuk menjalankan kemitraan konservasi yang berdasarkan pada perjanjian kerjasama dengan KPA atau KSA.

Pada tahun 2018 lalu sudah dibentuk 11 KTHK di TNGL untuk menjalankan kemitraan konservasi pada kawasan yang telah disepakati, dan pada tahun ini di identifikasi akan ada kelompok baru untuk mendukung optimalisai program kemitraan kehutanan di Resor Sekoci-Lepan TNGL. Sebagai salah satu target nasional (stategi nasional) kementerian kehutanan kemitraan koservasi menekankan pada partisipasi masyarakat desa yang ditinggal dikawasan penyanggah $\mathrm{TN}$.

Yayasan Pesona Tropis Alam Indonesia (PETAI) sebagai lembaga lokal yang concern pada konservasi dan pemberdayaan masyarakat, dengan dukungan dari Tropical Forest Conservation Action (TFCA-Sumatera) saat ini sedang mengimplementasikan program yang terfokus pada penguatan kapasitas KTHK dalam mengimplementasikan Kemitraan Konservasi. Maka PETAI akan memfasilitasi pembentukan kelompok tani hutan yang baru dimulai dari persiapan kelompok hingga pembuatan Perjanjian Kerjasama.

Dengan konsep kemitraan dalam meningkatkan pelayanan kepada UMKM, konsep petai ini dapat meningkatkan kualitas barang dan jasa. Konsep ini dikembangkan melalui pelatihan secara lang yang menjadi pemikiran pola pelayanan kepada konsumen agar dapat terus meningkatkan minat beli terhadap produk yang akan disajikan kepada pelanggan (Putra \& Damanik, 2020)

Dalam mewujudkan ekonomi kreatif, langkah awal yang dibutuhkan oleh UMKM diperlukan fsilitas khusus dari pemerintah khususnya dalam meningkatkan kualitas kewirausahaan sebagai peran 
utama serta strategi pengembangan program pemberdayaan. Komoditas usaha yang dihasilkan dapat berupa barang atau jasa yang selanjutnya merupakan salah satu modal dasar mahasiswa berwirausaha dan memasuki pasar. Jadi pemeran utama berwirausaha dalam hal ini adalah mahasiswa, bukan masyarakat, ataupun mitra lainnya (Putra, 2015). Universitas Al Azhar khususnya fakultas ekonomi menumbuhkan jiwa kewirausahaan dengan mengikuti kegiatan pendamping yang sudah pakar di bidangnya dengan kekuatan semangat kewirausahaan dapat ditransfer kepada UMKM yang berada di Sumatera Utara serta melakukan pendampingan dengan UMKM secara rutin.

Untuk mengembangkan wawasan kewirausahaan, UMKM perlu terus belajar dalam meningatkan kualitas produk untuk menghaslkan kreatifitas dan dapat meningkatkan suatu wilayah menjadi lebih maju dan perlu mengambil inspirasi dari wilayah yang lain yang turut serta dalam mengembangkan wilayah sebagai konsep studi banding (Syarifah \& Putra, 2017).

Jiwa kewirausahaan konsep dasar yang diperlukan dalam mengelola usaha yang merupakan sikap dan perilaku yang berkembang sdengan ditunjukkan melalui sifat, karakter, dan watak seseorang yang memiliki kemauan dalam mewujudkan gagasan inovatif kedalam dunia nyata secara kreatif ( Putra \& Aginta, 2019).

Proses kewirausahaan menuntut kemauan untuk mengambil resiko dengan perhitungan yang terukur sehingga dapat mengatasi rintangan untuk mencapai kesuksesan yang diharapkan. Pada umumnya, wirausahawan menggunakan kemampuannya untuk memanfaatkan sumberdaya yang terbatas (Putra \& Dilham, 2017)

Wirausaha ditujukan pada orang-orang yang dapat berdiri sendiri. Hal ini dapat diartikan sebagai orang-orang yang dapat mengembangkan diri sendiri dan mampu menjadikan konsep produk barang dan jasa berkembang dari waktu ke waktu dengan inovasi (Malawat \& Malawat, 2019) .

Kewirausahaan adalah merupakan suatu proses yang dinamik atau suatu rangkaian kegiatan yang dilaksanakan oleh para entrepreneurship di dalam usahanya untuk menghasilkan dan memberi nilai tambah bagi produk atau jasa tertentu yang telah diperjuangkan dengan gigih sehingga berhasil mendapatkan keuntungan atau keberhasilan secara komersial (Putra \& Ami, 2017)

Memahami kreativitas (daya cipta) akan memberikan dasar yang kuat untuk membuat modul atau perangkat tentang kewirausahaan. Peran sentral dalam kewirausahaan adalah adanya kemampuan yang kuat untuk menciptakan (to create or to innovate) sesuatu yang baru, misalnya : sebuah organisasi baru, pandangan baru tentang pasar, nilai-nilai corporate baru, proses-proses manufacture yang baru, produkproduk dan jasa-jasa baru, cara-cara baru dalam mengelola sesuatu., cara-cara baru dalam pengambilan keputusan (Siagian et al., 2019)

Seseorang dengan intensi untuk berwirausaha akan memiliki kesiapan dan kemajuan yang lebih baik dalam usaha yang dijalankan dibandingkan seseorang tanpa intensi berwirausaha. Intensi kewirausahaan diyakini berkaitan dengan perilaku terbukti dapat menjadi cerminan dari perilaku yang sesungguhnya. Oleh karena itu pemahaman tentang intensi seseorang untuk berwirausaha (entrepreneurial intention) dapat mencerminkan kecenderungan orang untuk mendirikan usaha secara riil (Malawat \& Putra, 2018)

Karakteristik Kewirausahaan merupakan kualitas atau sifat yang tetap terus menerus dan kekal yang dapat dijadikan ciri untuk mengidentifikasikan seorang pribadi, suatu objek, suatu kejadian, intergrasi atau sintesis dari sifat-sifat individual dalam bentuk suatu atau kesatuan dan kepribadian seseorang, dipertimbangkan dari titik pandangan etis dan moral. Sementara sikap kewirausahaan adalah 
sikap seseorang yang mempunyai $n$-ach yang tinggi dari kehidupan sehari-hari atau ciri-ciri sikap seorang wirausaha ( Putra et al., 2019)

Apa yang dilakukan dalam wirausaha dan bisnis akan cepat berkembang jika mampu mempergunakan modal sosial dalam wirausaha. Mereka yang memiliki tingkat yang lebih besar dari modal manusia lebih rentan untuk menemukan peluang yang dianggap cukup menarik untuk memicu mengambil langkah-langkah untuk menuju memulai bisnis mereka sendiri dibandingkan dengan yang tidak memiliki (Putra et al., 2017)

Permasalahan utama yang akan diteliti ini adalah:

1. Bagaimana penerapan pengetahuan, pemahaman Pentingnya Kepemimpinan kewirausahaan dalam menjalankan KTHK sehingga bisa mengarahkan kelompok-kelompok dibawah naungan KTHK dengan baik?

2. Bagaimana Peserta mengarahkan kepada analisis SWOT?

\section{Realisasi Kegiatan}

Dalam konsep pengajaran Konsep kewirausahaan yang merupakan inti dari materi perkuliahan kepada 2 kelompok wirausaha sekitar gunung leuser Besitang yang mendapatkan banyak manfaat secara langsung dari konsep kewirausahaan yaitu :

\section{A. Implementasi Konsep Kepemimpinan Kewirausahaan}

Dengan penggunaan faktor produksi, wirausaha merupakan merupakan faktor produksi aktif yang dapat menggerakkan dan memanfaatkan sumberdaya lainnya seperti sumber daya alam, modal dan teknologi sehingga dapat menciptakan kekayaan dan kemakmuran melalui penciptaan lapangan kerja, penghasilan dan produk yang diperlukan masyarakat karena itu pengembangan kewirausahaan merupakan suatu keharusan dalam pembangunan sejalan dengan penelitian. Jiwa kewirausahaan merupakan nyawa kehidupan dalam kewirausahaan yang pada prinsipnya merupakan sikap dan perilaku kewirausahaan dengan ditunjukkan melalui sifat, karakter, dan watak seseorang yang memiliki kemauan dalam mewujudkan gagasan inovatif kedalam dunia nyata secara kreatif. Karakter yang perlu dikembangkan merupakan suatu hal yang ditimbulkan melalui grup bisnis yang merupakan output dari mata kuliah kewirausahaan sesuai dengan pemaparan dari Putra \& Damanik, 2020, Putra, 2015, Putra, 2015, Putra \& Aginta, 2019.

Proses kewirausahaan menuntut kemauan untuk mengambil resiko dengan penuh perhitungan sehingga dapat mengatasi rintangan untuk mencapai kesuksesan yang diharapkan. wiraswasta pada mula-nya ditujukan pada orang-orang yang dapat berdiri sendiri. Di Indonesia kata wiraswasta sering diartikan sebagai orang-orang yang tidak bekerja pada sektor pemerintah yaitu; para pedagang, pengusaha, dan orang-orang yang bekerja di perusahaan swasta, sedangkan wirausahawan adalah orang-orang yang mempunyai usaha sendiri sesuai dengan pemaparan Putra \& Dilham, 2017, Malawat \& Malawat, 2019, Putra \& Ami, 2017.

Kewirausahaan merupakan suatu proses yang dinamik atau suatu rangkaian kegiatan yang dilaksanakan oleh para entrepreneurship di dalam usahanya untuk menghasilkan dan memberi nilai tambah bagi produk atau jasa tertentu yang telah diperjuangkan dengan gigih sehingga berhasil mendapatkan keuntungan atau keberhasilan secara komersial. Hal ini dapat menciptakan kreativitas (daya cipta) akan memberikan dasar yang kuat untuk membuat modul atau perangkat tentang kewirausahaan. Peran sentral dalam kewirausahaan adalah adanya kemampuan yang kuat untuk menciptakan (to create or to innovate) sesuatu yang baru, misalnya : sebuah organisasi baru, pandangan 
baru tentang pasar, nilai-nilai corporate baru, proses-proses manufacture yang baru, produk-produk dan jasa-jasa baru, cara-cara baru dalam mengelola sesuatu., cara-cara baru dalam pengambilan keputusan sesuai dengan pemaparan sesuai dengan pemaparan Siagian et al., 2019, Malawat \& Putra, 2018.

Dengan cara-cara yang baru, dapat meningkatkan intensi berwirausaha dan dapat menjadikan mahasiswa dapat menciptakan usaha yang riil. Hal ini sejalan dengan memaparkan bawah seseorang dengan intensi untuk berwirausaha akan memiliki kesiapan dan kemajuan yang lebih baik dalam usaha yang dijalankan dibandingkan seseorang tanpa intensi berwirausaha. Intensi kewirausahaan diyakini berkaitan dengan perilaku terbukti dapat menjadi cerminan dari perilaku yang sesungguhnya. Oleh karena itu pemahaman tentang intensi seseorang untuk berwirausaha (entrepreneurial intention) dapat mencerminkan kecenderungan orang untuk mendirikan usaha secara riil. Hal ini menguatkan pendapat dari karakteristik kewirausahaan merupakan kualitas atau sifat yang tetap terus menerus dan kekal yang dapat dijadikan ciri untuk mengidentifikasikan seorang pribadi, suatu objek, suatu kejadian, intergrasi atau sintesis dari sifat-sifat individual dalam bentuk suatu atau kesatuan dan kepribadian seseorang.Munculnya semangat baru dalam berwirausaha menjadi modal besar dalam pembangunan dan memicu untuk mengelola bisnis secara efektif sejalan dengan pemaparan menjelaskan bahwa dilakukan dalam wirausaha dan bisnis akan cepat berkembang jika mampu mempergunakan modal sosial dalam wirausaha. Mereka yang memiliki tingkat yang lebih besar dari modal manusia lebih rentan untuk menemukan peluang yang dianggap cukup menarik untuk memicu mengambil langkah-langkah untuk menuju memulai bisnis mereka sendiri dibandingkan dengan yang tidak memiliki sesuai pemaparan dari Putra et al., 2017.

\section{B. Implementasi Hasil Program Pemberdayaan di Sekitar Gunung Leuser Besitang}

Dari hasil pendalaman materi yang diadopsi oleh teori kewirausahan, terciptalah ide baru kewirausahaan yang telah dituangkan melalui grup bisnis sebanyak 2 grup bisnis yang membuat proposal bisnis plan bertajuk program pembedayaan kelompok. Dari 2 grup bisnis yang turut serta telah melakukan FGD untuk bisa mendapatkan hasil kewirausahaan yang untuk mewujudkan Ekonomi Kreatif . Untuk penggerakan suatu faktor produksi, Setiap kelompok sudah menerapkan suatu pembaharuan pengembangan kewirausahaan untuk pembangunan ekonomi masyarakat Asahan.

Jiwa kewirausahaan merupakan nyawa kehidupan dalam yang mengetengahkan produk yang belum pernah dibuat sebelumnya. Proses kewirausahaan menuntut kemauan dari2 grup bisnis untuk menciptakan suatu inovasi. Dari Gambar 1 dapat terlihat suatu proses yang dinamik atau suatu rangkaian kegiatan yang dilaksanakan oleh para grup bisnis di dalam usahanya untuk menghasilkan dan memberi nilai tambah bagi produk yang menciptakan suatu pembaharuan dari usulan proposal yang diharapkan. intensi untuk berwirausaha akan memiliki kesiapan dan kemajuan yang lebih baik dalam usaha karakteristik kewirausahaan merupakan kualitas dan terus menerus wirausaha akan cepat berkembang jika mampu mempergunakan modal sosial dalam wirausaha

Tabel 1. Usulan Proposal Program Pemberdayaan Komunitas

\begin{tabular}{|l|l|}
\hline \multicolumn{1}{|c|}{ Nama Pengusul } & \multicolumn{1}{c|}{ Usulan Proposal Program Kegiatan } \\
\hline Hasanuddin & Proposal Pemberdayaan Kelompok Petani Sayur \\
\hline Herri & Proposal Pemberdayaan Kelompok Petani Buah-Buahan \\
\hline
\end{tabular}


Dari grup bisnis tersebut telah melakukan testimony produk kepada beberapa dosen dan beberapa calon pelanggan secara keseluruhan menghasilkan beberapa analisis dengan menggunakan analisis SWOT (Strength, Weakness, Opportunity, Threat). Analisis ini digunakan untuk melihat produk yang dihasilkan dengan konsep teori yang baik dipadukan dengan hasil output yang dihasilkan untuk dapat menimbulkan kelayakan dalam pemasaran.

\section{Hasil}

Pemasaran yang diharapkan akan meningkatkan untuk menemukan peluang yang dianggap cukup menarik untuk memicu mengambil langkah-langkah untuk menuju memulai bisnis mereka sendiri dibandingkan dengan yang tidak memiliki. Dari hasil testimony yang dihasilkan, terdapat beberapa analisis :

Tabel 2. Analisis SWOT Pemberdayaan Petani

STRENGTH: $\quad$ WEAKNESS:

- Produk sayur dan buah-buahan banyak diminati konsumen

- Produk ini tidak membutuhkan inovasi terlalu sulit

- Mendapat pelatihan secara berkala
- Dari segi kemasan produk belum sesuai harapan

- Belum memiliki label usaha.

- Produk cepat rusak

- Bahan baku telat maka proses produksi akan telat juga

- Produk akan mudah ditiru

- Pengendalian masalah yang kurang terkontrol.

\section{THREAT:}

- Resiko yang akan dihadapi dalam usaha produk ini adalah persaingan ketat dari produk merek lain berupa harga dan kemasan. Semakin rasa dan kemasan yang menarik semakin banyaknya peminat.

- Peluang bisnis produk ini sangat menjanjikan. 
- Inovasi produk

- Pengembangan usaha dengan konsep investasi dan mngembangkan ide-ide yang menarik dari setiap anggota

Dengan hasil yang dilakukan dari Pemberdayaan Petani di Sekitar Gunung Leuser Besitang searah dengan arahan pendidikan dikti yang diutamakan dari teori yang telah dipaparkan oleh beberapa peneliti sebelumnya. Dasar yang telah dilaksanakan secara maksimal menjadikan mahasiswa mendapat modal usaha untuk peningkatan pembangunan di Kabupaten Langkat.

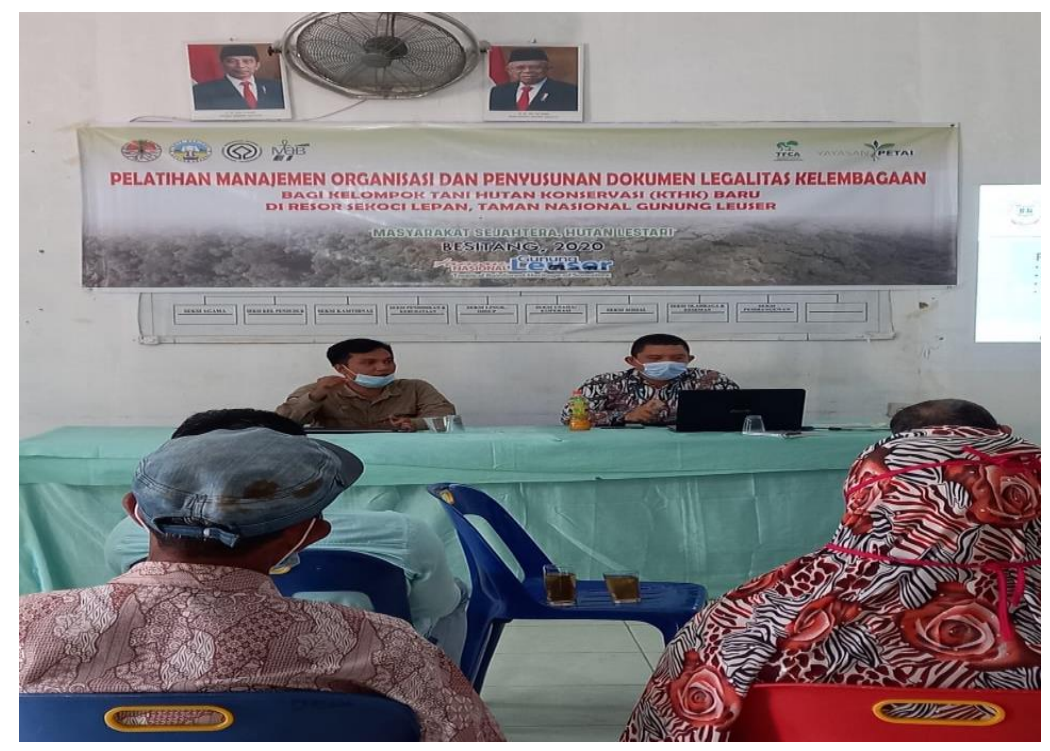

Gambar 1. Pelatihan Kewirausahaan Kepada Petani Gunung Leuser

Untuk kedepannya, PkM ini akan terus dikembangkan ke pembuatan laporan keuangan dan manajemen organisasi untuk memperkuat bisnis di Kabupaten Langkat. Bagi kelompok yang berkompten dalam mengelola bisnis dapat melatih kelompok lain di tingkat bawah untuk memulai bisnis dengan baik lagi dan terus menciptakan produk baru yang dapat bersaing di pasar dalam maupun luar Kabupaten Langkat. Konsep pembelajaran ini, akan terus dievaluasi dan dikembangan menuju kepada pencapaian yang lebih baik lagi.

\section{A. Kesimpulan}

\section{$\underline{\text { Kesimpulan }}$}

Dari hasil penerapan perkuliahan dengan menerapkan program pemberdayaan petani, yaitu:

- Implementasi Konsep Kewirausahaan dilaksanakan berdasarkan landasan teori yang dilaksanakan berdasarkan hasil landasan teori kewirausahaan.

- Implementasi Hasil Program Pemberdayaan dapat dihasil Analisis SWOT yang dilakukan melalui peltaihan kewirausahaan. 
- Perlu dilakukan komunikasi yang erat antara petani dan semua tim dengan baik.

\section{B. Saran}

- Diperlukan suatu komunitas untuk mewujudkan kemandirian usaha dan mendalami kajian kewirausahaan secara lebih khusus

- Perlunya bantuan dari pihak swasta dan pemerintah di Kabupaten Langkat memberikan inspirasi terhadap pengembangan jiwa kewirausahaan

\section{Ucapan Terimakasih}

Penulis mengucapkan terima kasih kepada Grup Petai atas dukungan sehingga terlaksana acara berlangsung dengan baik

\section{Daftar Pustaka}

Malawat, M. S., \& Putra, M. U. M. (2018). Review Of Implementation In Bunut Shoes Assistance Program In Order Of Micro, Small And Medium Enterprises Economic In Asahan Regency. Journal of Physics: Conference Series, 970(1), 1-6. https://doi.org/10.1088/17426596/970/1/012022

Muhammad Umar Maya, Putra., Ami, D. (2017). An Effectiveness Analysis of Corporate Social Responsibility of Empowerment Program in Terminal BBM Pertamina Siantar. 1987, 457-463.

Putra, Muhammad Umar Maya, \& Aginta, W. (2019). Pengembangan Manajemen Pemasaran Pada Klinik Bisnis Tebing Tinggi. Prosiding Seminar Nasional Riset Information Science (SENARIS), 1(September), 25. https://doi.org/10.30645/senaris.v1i0.4

Putra, M Umar Maya. (2015). Konsep Pengembangan Ekonomi Kerakyatan Di Kota Medan. 5(April), $1-9$.

Putra, M Umar Maya, Aginta, W., Al-azhar, U., Tinggi, T., Putra, M. U. M., \& Aginta, W. (2019). Analisis Program Klinik Bisnis ( Klibi ) Untuk Perkembangan Umkm Kota Tebing Tinggi. 9, 127136.

Putra, M. Umar Maya, \& Damanik, S. (2020). Service Implementation of Consumer Interest in Tebing Tinggi Business Clinic Sumatera Utara. International Journal of Research -GRANTHAALAYAH, 8(9), 200-208. https://doi.org/10.29121/granthaalayah.v8.i9.2020.1387

Putra, M Umar Maya, Damanik, S., Al, U., \& Medan, A. (2017). PENGARUH EKSPOR MIGAS DAN NON MIGAS TERHADAP. 7, 245-254.

Putra, M Umar Maya, \& Dilham, A. (2017). Kecamatan Dumai Timur ( Studi Kasus : Kelurahan Bukit Timah ). 7(April), 1-8.

Saleh, Malawat; M Umar Maya, P. (2019). Business start-up empowerment in asahan district 1. The 1st Multi-Discipinary International Conference University Of Asahan2019 Thema: The Role of Science in Development in the Era of Industrial Revolusion 4.0 Based on Local Wisdom. " in Sabty Garden Hotel-Kisaran North Sumatra, March 23rd, 2019 BUSINESS, 299-304.

Siagian, S., Putra, M. U., \& Yanti, M. (2019). Implementation of Interest in Buying Mikroskil Economic Students on Traveloka Online. https://doi.org/10.4108/eai.24-10-2019.2290561

Syarifah, Tengku; Putra, M. U. M., \& Syarifah, Tengku., M. Umar Maya, P. (2017). Motivation And Entrepreneurs Training For Tinggi Raja Society Of Asahan Regency. 2nd Annual International Seminar on Transformative Education and Educational Leadership (AISTEEL 2017) Motivation, 104(Aisteel), 1-5. http://aisteel.unimed.ac.id/wp-content/uploads/2017/05/ProceedingsAISTEEL_95.pdf 